\title{
Strategi Survivalitas Warga dan Politik Survivalitas Aktor Politik pada Konflik Pertambangan
}

\author{
Abdul Rozak ${ }^{1}$, Dede Sri Kartini², Yusa Djuyandi ${ }^{3}$ \\ 1,2,3 Pascasarjana Ilmu Politik, Universitas Padjadjaran
}

\begin{abstract}
Abstrak:
Artikel ini bertujuan untuk mendiskusikan bentuk strategi bertahan hidup yang diperankan warga masyarakat dan strategi mempertahankan kekuasaan dan pengaruh oleh pemilik kekuasaan dan pengaruh dalam konflik di wilayah kerja pertambangan panas bumi di Kabupaten Mandailing Natal, Provinsi Sumatera Utara tahun 2010-2015. Guna mengkaji masalah ini dipergunakan acuan teori relasi negaramasyarakat dari Joel S. Migdal (1988) dan teori perlawanan orang-orang lemah dan terpinggirkan oleh James Scott (1985). Data dikumpulkan melalui FGD, wawancara mendalam, observasi dan kajian pustaka serta dianalisa secara kualitatif. Kajian ini menemukan bahwa relasi negara-masyarakat yang terbangun adalah relasi yang menempatkan negara sebagai entitas yang lemah (weak state) dan menjadikan lembaga sosial sebagai entitas yang kuat (strong society). Pada situasi ini, warga dan elit politik serta kekuaasan menerapkan strategi dan politik survivalitas yang sifatnya konvensional dan inkonvensional seperti menggunakan pendekatan agama dalam melakukan perlawanan dan mempertahankan pengaruh. Kajian ini merekomendasikan perlunya instusi negara ditempatkan kembali sebagai lembaga yang kuat serta menjadi otoritas utama dalam melakukan kontrol sosial di tengah masyarakat.
\end{abstract}

\section{Kata Kunci:}

konflik; tambang geothermal; strategi bertahan hidup; politik survival; pemilu

\section{Pendahuluan}

ehadiran perusahaan eksplorasi panas bumi di bawah bendera PT.
Sorik Marapi Geothermal Power (PT. SMGP) di Kabupaten
Mandailing Natal (Madina) sejak tahun 2010 sampai tahun 2015 telah menimbulkan polemik di tengah masyarakat. Perusahaan di bawah konsorsium perusahaan multinasional ini (Origin dari Australia, Tata Power dari India serta Supraco dari Indonesia) akan mengeksplorasi panas bumi untuk kebutuhan listrik dengan potensi 240 MW (Sagala, Chandra, \& Purba, 2016). Potensi tersebut diyakini dapat membantu mengatasi kebutuhan listrik di provinsi Sumatera Utara. Namun demikian, kehadiran 
perusahaan serta kegiatan eksplorasi menyebabkan masyarakat terbelah dalam dua kelompok yang berseberangan. Satu sisi masyarakat mendukung eksplorasi dengan pertimbangan peningkatan ekonomi dan pengembangan wilayah dan pada sisi lain menolak dengan tegas disertai pertimbangan akan potensi kerusakan alam dan lingkungan. Kelompok masyarat penolak tambang membentuk organisasi pergerakan dengan nama Forum Masyarakat Lereng Sorik Marapi atau pada kesempatan lain menamakan diri sebagai Forum Penolakan OTP/SMGP.

Forum tersebut melakukan sebuah gerakan sosial yaitu tantangan kolektif atas kelompok elit, lawan dan pengusa yang dilakukan sekelompok orang yang memiliki nilai, solidaritas dan tujuan yang sama (Hasan, 2006; Kilgore, 1999). Kelompok ini dalam waktu yang relatif singkat berhasil mempengaruhi masyarakat untuk mengusir perusahaan tambang sekaligus menjadi kekuatan sosial dominan yang memiliki kontrol sosial di tingkat desa sampai kecamatan melampaui kontrol yang seharusnya diperankan oleh negara. Forum ini merangkul semua elemen masyarakat mulai dari tokoh adat, agama, pemuda, kelompok perempuan sampai pada pejabat pemerintahan. Kelompok ini berhasil menerapkan reward bagi mereka yang mendukung dan memberlakukan punishment bagi siapapun yang menghalangi sehingga gerakan penolakan aktifitas tambang dengan cepat mendapatkan legitimasi dari masyarakat (Migdal, 1988). Reward yang ditawarkan bukanlah insentif material melainkan insentif sosial seperti perlindungan dari rasa aman dan nyaman bagi warga yang sedang berkonflik akibat aktifitas tambang. Pemberlakuan sanksi diterapkan secara beragam mulai dari pemboikotan acara adat/keluarga bagi warga yang mendukung perusahaan, provokasi, intimidasi, kekerasan fisik sampai pada pembunuhan.

Forum penolakan tambang merupakan suatu bentuk kekuasaan dalam wujud yang abstrak atau samar-samar (Haris et al., 2014) dan sesuai dengan visinya berhasil memaksa pemerintah daerah untuk mencabut izin usaha pertambangan (IUP) melalui Keputusan Bupati Madina Nomor: 540/665/K/2014. Namun demikian, perubahan regulasi nasional tentang kegiatan panas bumi melalui UU Nomor 21 Tahun 2014 mengalihkan kewenangan pemberian IUP dari pemerintah kabupaten/kota menjadi kewenangan pemerintah pusat. Regulasi itu pada gilirannya menjadi dasar hukum pemberian kembali IUP kepada perusahaan awal tahun 2015. Sekalipun regulasi berubah, forum penolakan tetap menjalankan aksinya menolak kegiatan pertambangan dan pada puncaknya melakukan penyerangan kepada beberapa oknum masyarakat yang membela kehadiran perusahaan di desa Maga Lombang tanggal 20 Januari 2015. Penyerangan itu menyebabkan tewasnya seorang warga sekaligus tokoh pendukung kehadiran perusahaan. Berdasarkan putusan pengadilan, korban tersebut dibunuh langsung oleh pimpinan forum penolakan, Herman Nasution, dibantu oleh 9 anggota forum lainnya . 
Konflik yang terjadi di wilayah pertambangan panas bumi Sorik Marapi secara teoritik dapat dianalisa dengan menggunakan teori relasi negara-masyarakat (statesociety relation) yang dikemukakan oleh Joel S. Migdal (Migdal, 1988). Konflik itu terjadi karena institusi negara mengalami "pelapukan" dan gagal melakukan kontrol sosial yang seharusnya diperankan oleh negara jauh sebelum konflik itu muncul. Relasi negaramasyakat yang menempatkan institusi sosial sebagai pengambil kontrol sosial menyebabkan negara atau otoritas pemerintah setempat berada pada posisi yang lemah (weak state). Dalam kondisi tersebut, gerakan sosial dan perlawanan untuk mengusir aktifitas tambang dikordinir oleh institusi sosial dengan melakukan beragam bentuk perlawanan masyarakat lemah dan terpinggirkan seperti disampaikan oleh James Scott dalam kajiannya di wilayah pedesaaan Sedaka, Kedah, Malaysia (Scott, 2008). Dalam sebuah masyarakat yang berkonflik dan hadirnya institusi sosial yang kuat, warga negara menerapkan strategi bertahan hidup (strategy of survival) demi menjaga kepentingan keselamatan dirinya dan para aktor politik atau mereka yang memiliki kekuasaan dan pengauh menerapkan politik mempertahankan pengaruh dan kekuasaan itu (politic of survival) (Migdal, 1988).

\section{Strategi Survival dan Politik Survivalitas sebagai Topik Kajian}

Menurut McMann (2015) peran para aktor bukan negara (non-state actor) dalam sebuah masyarakat akan mempengaruhi pola hubungan negara-masyarakat itu. Pada kondisi negara lemah (weak state) dan masyarakat kuat (strong society) misalnya, unit-unit sosial menawarkan beragam pilihan yang dinilai menguntungkan bagi warga. Hal ini terjadi karena negara dianggap gagal dalam menjalankan peran-peran normatifnya dan pada saat yang sama individu yang hidup dalam sebuah komunitas membutuhkan rasa aman (safety and security) (Abbass, 2012; Sjaf, 2014). Pada situasi ini individu akan memenuhi kebutuhan psikologisnya dengan menerapkan strategies of survival yaitu bagaimana bertahan dalam situasi sulit dan membuat pilihan terbaik di antara beragam alternatif serta menjadikan pilihan tersebut sebagai "blue-print" dalam bersikap dan bertindak (Migdal, 1988). Ketika unit sosial dapat menyajikan beragam sumber daya, institusi negara akan mengalami kesulitan dalam memobilisasi warga dan warga sendiri akan enggan menerima manfaat dari pemerintah. Studi James Scott di Kedah Malaysia, misalnya, menunjukkan bagaimana petani miskin dalam keterbatasannya masih memiliki alternatif pilihan untuk tetap eksis di tengah masyarakat dengan bergabung atau setidaknya tidak mengganggu kelompok penguasa demi kepentingan ekonomi atau memilih bergabung dengan kelompok oposisi demi menjaga harga diri sesuai afiliasi politik turun-temurun maupun menjaga marwah sebagai orang Melayu dan Islam (Scott, 2008).

Jika warga menerapkan strategy of survival maka para aktor politik maupun pemilik kekuasaan menerapkan politic of survival yaitu strategi para aktor politik dan 
kekuasaan untuk mempertahankan posisi maupun kekuasaannya dalam situasi konflik itu (Migdal, 1988). Pelabelan terminologi "politik" pada bentuk survivalitas ini tidak terlepas dari tujuan para aktor ini adalah untuk merawat dan mempertahankan kekuasaan dan pengaruh mereka karena pada dasarnya pusat perhatian politik tidak pernah lepas dari kekuasaan atau pengaruh (power). Dalam kehidupan politik normatif (on the daily basis) mereka akan berusaha menempatkan posisi pada tempat yang tepat untuk mempertahankan kekuasaan dan pada moment politik tertentu, seperti pada saat kontestasi pemilu yang tentunya dapat merubah struktur pemerintahan lokal yang berimbas pada mereka, para aktor ini akan berlaku oportunitis dan pragmatis demi mengamankan kekuasaan di masa yang akan datang. Konflik yang terjadi di wilayah pertambangan panas bumi Sorik Marapi berlangsung dalam periode yang sama dengan penyelenggaraan kontestasi pemilu khususnya Pemilukada Bupati Tahun 2015. Dalam sebuah kontestasi pemilu, strategi mereka dapat saja dilakukan secara lunak atau bahkan dengan menggunakan kekerasan fisik, intimidasi atau kekerasan untuk memastikan hasil pemilu (Fjelde \& Höglund, 2016). Migdal menyatakan begitu banyak pemimpin negara yang menyadari masa jabatannya tergantung pada stabilitas sosial dan kelompok sosial tertentu sehingga dapat saja para aktor politik maupun pemilik kekuasaan itu bekerjasama (Lambach, 2004). Dalam kajian Migdal terdapat 3 (tiga) bentuk utama politik bertahan hidup dalam mempertahankan dominasi, kontrol sosial maupun mobilisasi di tengah-tengah masyarakat seperti big shuffle (perombakan secara massif struktur kelembagaan), non merit appointment (penunjukan pejabat tanpa kualifikasi dan kelayakan) dan dirty trick (trik licik atau kotor) (Migdal, 1988).

Dalam penulisan artikel ini, penulis melakukan penelitian kualitatif dengan menggunakan data primer dan data sekunder. Data primer diperoleh melalui obervasi, wawancara, diskusi kelompok (group discussion) maupun diskusi kelompok terarah Focussed Group Discussion (FGD). Data sekunder terdiri atas data statistik, data kepemiluan, dokumen internal forum penolakan tambang dan studi yang relevan dengan permasalahan yang dikaji. Analisa data dilakukan secara kualitatif sesuai siklus atau spiral analisis data sebagaimana disampaikan (Creswell, 2015). Validitas data dilakukan melalui pendekatan triangulasi pengumpulan data, sumber data dan teori. Triangulasi teori secara khusus dilakukan dengan menempatkan teori relasi negara-masyarakat (Lambach, 2004) sebagai teori pokok dan menempatkan beberapa teori pendukung seperti teori kekuasaan, teori gerakan sosial (Hasan, 2006) maupun teori perilaku memilih (Evans, 2004).

\section{Strategi Survival Warga Pro Tambang}

Strategi survivalitas seperti diungkapkan Migdal (1988) adalah tindakan, sikap atau langkah yang dilakukan oleh warga biasa (individual citizen) yang tidak memiliki pengaruh dan kekuasaan politik dalam sebuah masyarakat. Pada kasus konflik di wilayah 
pertambangan panas bumi Sorik Marapi, Mandailing Natal, bentuk survivalitas masyakat pro atau netral atas aktifitas tambang antara lain ditunjukkan dengan tindakan kepatuhan palsu (false compliance), membentuk kelompok perlawanan, perlawanan diam-diam dan sikap kepura-puraan.

Bentuk strategi survivalitas yang dilakukan oleh warga yang pro terhadap aktifitas tambang sangat beragam salah satunya adalah kepatuhan palsu terhadap kelompok sosial dominan. Gerakan sosial dan konflik di kawasan WKP Sorik Marapi sejak tahun 2010 terus membesar dan melibatkan banyak pihak. Sebagaian besar warga lebih banyak menurut atau patuh atas aturan yang dibuat oleh forum penolakan tambang karena penolakan akan kehendak kelompok dominan dapat mendatangkan sanksi seperti pengusiran, pengucilan, pemboikotan acara-acara keluarga dan ancaman lainnya (Migdal, 1988; Scott, 2008). Bentuk kepatuhan warga ditunjukkan antara lain dengan memberikan sumbangan sukarela manakala pengurus forum penolakan mendatangi rumah warga door to door untuk mengambil beras pungut maupun mengutip uang. Beras dan sumbangan itu biasanya dipungut jika ada acara zikir akbar, demonstrasi atau keperluan menyaksikan persidangan para tersangka/terdakwa di pengadilan.

"Biasa itu mereka minta truk kita dipakai untuk acara zikir akbar dan acara lainnya.

Biasanya supir saya akan melapor, "mau dipakai orang itu katanya mobil kita". Saya bilang aja kasih. Dan tidak ada cerita berapa sewanya di situ. Saya pun tidak pernah tanya kenapa tidak disewa dengan layak. Yang penting mereka tidak macam-macam dan kita aman."

Nasiruddin Lubis, informan lainnya, menyampaikan bahwa ia hampir tidak pernah menghadiri acara yang dilakukan oleh forum penolakan dan kelompok penolakan mungkin memahami situasi beliau karena selalu sibuk dengan pekerjaannya sebagai PNS. Namun ketika ada permintaan sumbangan uang maupun beras secara door to door ia selalu memberikannya tanpa banyak bertanya untuk keperluan apa sumbangan itu dikutip. Pun demikian, ketika salah satu tokoh penolakan datang menemuinya untuk meminjamkan uang untuk pergerakan ia berikan walaupun ia melakukannya biar tidak ada pengucilan dari mayoritas masyarakat anti tambang .

Strategi bertahan hidup yang dilakukan oleh masyarakat pro tambang selanjutnya adalah mmementuk kelompok perlawanan. Forum penolakan tambang awalnya menginisiasi terbentuknya norma tertulis yang dalam istilah lokal disebut dengan "undang-undang desa" - semacam berita desa yang memuat aturan tentang tindakan yang dilarang dan diperbolehkan karena hadirnya aktifitas tambang. Norma ternyata sangat legitimate khususnya pada desa yang dianggap paling keras melakukan penolakan. Desa Hutabaru, Handel dan Sibanggor Julu adalah beberapa desa yang teguh menjalankan vonis seperti apa yang tertulis pada norma tersebut. Di antara butir norma itu disebutkan bahwa setiap warga yang terbukti bekerja dengan perusahaan tambang, menjual lahan kepada perusahaan maupun sekedar menerima tamu dari perusahaan 
akan diberikan hukuman sosial dan adat berupa pemboikotan acara siriaon (pesta) maupun siluluton (musibah) pada keluarga warga yang melanggar norma serta dapat diusir dari desa. Pemberlakuan suatu norma dan beragam aturan seperti ini merupakan strategi yang dilakukan oleh kelompok sosial dominan dalam mempertahankan kontrol sosialnya (Moyo, 2014).

Pemberlakuan norma itu terbukti efektif dan banyak warga masyarakat pada masing-masing desa di WKP Sorik Marapi yang dikenakan hukuman karena secara nyata mendukung atau dicurigai mendukung kegiatan tambang. Karena banyaknya kasus pemboikotan siriaon dan siluluton pada banyak warga, muncul kelompok sosial baru yang merangkul warga yang pro maupun netral atas kegiatan tambang yang menggantikan peran lembaga adat yang secara konvensional telah hadir dalam budaya lokal. Kelompok baru ini dipimpin oleh Ismail Tanjung, seorang warga yang sebelumnya pernah bekerja sebagai helper pada perusahaan. Kelompok ini diberi nama STM Dalihan Natolu dan memiliki AD/ART serta mengharuskan anggotanya membayar iuran rutin setiap bulannya. Kelompok ini sangat solid dan boleh dikatakan mengalahkan solidnya lembaga adat yang secara tradisional sudah terbentuk sejak dahulu.

"Alasan saya dan Saudara Bincar membuat STM Dalihan Natolu tidak lain bahwa sudah terjadi kerusakan sosial yang sangat parah di desa ini. Banyak warga yang acara siriaon-nya tidak dihadiri. Malah yang satu marga seperti persatuan Lubis pecah menjadi dua. Satu hatobangan sebagai penolak tambang dan satu hatobangan yang lain pro tambang. Saya juga termasuk menjadi korban kerusakan sosial itu. Orang tua saya meninggal, yang sudah sangat sepuh di kampung ini, hanya segelintir orang yang datang. Malah keluarga paling dekat sekalipun tidak hadir buat sekedar mengucapkan bela sungkawa".

Bentuk perlawanan yang diperankan oleh warga yang pro tambang selanjutnya adalah tindakan kepura-puraan. Tindakan kepura-puraan adalah salah satu bentuk perlawanan yang lazim dilakukan oleh kelompok sosial rentan terhadap hegemomi politik maupun ekonomi kelompok elit (Scott, 2008). Pada kajian ini, forum penolakan tambang melakukan beberapa kali gelaran sumpah di bawah Al Qur'an untuk memastikan semua warga pada semua desa steril dari pendukung aktifitas tambang. Banyak warga pro tambang menyatakan sumpah yang diikutinya adalah bentuk kepura-puraan karena tidak mungkin menolak dan berseberangan dengan kelompok sosial dominan. Khoirul Bahri menceritakan bagaimana ia dan teman-temannya dijemput untuk melaksanakan sumpah untuk penolakan aktifitas tambang. Pada hari digelar sumpah massal di Sibanggor Julu, ia menyaksikan beberapa pemuda datang menjemputi warga yang masih berkeliaran di tengah desa. Khawatir akan diarak dan diperlakukan sama dengan yang lain, ia beranjak menuju gedung serba guna tempat dilakukannya zikir akbar. Ketika sampai di sana, ia disuruh mengambil tempat untuk disumpah. Ia mengatakan kalau misalnya ada jendela gedung yang bisa dilompati ia akan melakukan itu. Tapi, itu tidak mungkin karena bisa 
saja massa yang menjadi lawannya. Pada gilirannya, ia pun mengambil tempat untuk disumpah dan mengikuti redaksi apa yang disampaikan oleh pengambil sumpah.

"Kalau memang bisa melompat dan melarikan diri saya sudah melompat. Ada beberapa orang yang saya lihat "meos-keos" (gelisah) karena akan melakukan sumpah itu. Saya terpaksa mengikutinya saja walaupun dalam hati tidak sepenuhnya iklas bersumpah itu"

Sama seperti bentuk perlawanan lain yang ditunjukkan kelompok petani miskin dalam kasus petani di Kedah, Malaysia, bentuk perlawanan lain yang dilakukan oleh warga pro tambang adalah perlawanan diam-diam (silent resistance) (Scott, 2008). Hal ini misallnya dilakukan oleh seorang warga desa, Siddik Tanjung, pekerja pada perusahaan tambang, yang membisikkan pada beberapa warga desa bahwa pengurus penolakan dari sayap pemuda telah menerima uang dari perusahaan. Siddik Tanjung, ketika gerakan sosial sedang memuncak dan santernya isu pengusiran bagi pekerja tambang memilih pindah dari desa untuk bertempat tinggal di wilayah Purbalamo, dekat dengan basecamp perusahaan. Tidak terima dengan kondisi itu, ia membalas dendam dengan membisikkan pada beberapa orang bahwa ia pernah melihat ada dua orang pengurus forum penolakan membawa proposal untuk acara yang digelar forum. Untuk meyakinkan atas informasinya, ia turut menunjukkan photo kuitansi penerimaan uang sebesar Rp. 10 juta. Informasi itu cepat menyebar sehingga segera dilakukan rapat akbar di desa untuk mengklarifikasi isu itu. Syarifuddin alias Fuddin Lubis, mantan ketua forum muda-mudi Sorik Marapi menuturkan bahwa kejadian itu benar apa adanya dan itu terjadi kepada Amsir dan Sul Tanjung.

"Ada masa itu acara Maulid Nabi dan seluruh warga puncak diundang untuk acara itu sekaligus memasak lemang secara massal. Ada yang mengakuinya mereka menerima uang dari perusahaan. Si Siddik yang menyampaikan. Setahu saya memang uangnya sama mereka semua. Memang ada kecurigaan kita masa itu, selama ini rokoknya IN-MILD ini kok SAMPOERNA Mild terus. Usir kata orang ramai akhirnya setelah ketahuan"

\section{Strategi Survival Warga Anti Tambang}

Konflik di wilayah pertambangan panas bumi Sorik Marapi seperti disampaikan sebelumnya telah membelah masyarakat dalam dua kubu yang berseberangan. Jika pada bahagian sebelumnya dijelaskan tentang strategi yang diterapkan oleh masyarakat pro tambang maka selanjutnya diperlihatkan bentuk survivalitas warga anti tambang. Strategi yang mereka tunjukkan kontras dengan strategi yang diterapkan oleh warga pro tambang seperti tindakan mempersenjatai diri, tindakan penyamaran, gerilya dari pengejaran polisi, membantu logistik para pelarian serta mendesak kepolisian menangkap pihak lawan. 
Secara teoritik, gerakan sosial merupakan sebuah perjuangan meruntuhkan dominasi sebuah rezim yang dianggap otoriter menuju rezim yang demokratis (Oliver, Cadena-Roa, \& Strawn, 2003). Berbagai langkah dilakukan oleh warga anti tambang untuk bertahan dari kungkungan rezim yang mereka anggap otoriter tersebut termasuk melakukan pembelaan diri dengan tindakan mempersentajatai diri. Kelompok anti tambang dalam kajian ini juga melakukan hal yang serupa yakni melindungi atau mempersenjatai diri khususnya ketika melakukan aksi massa pada banyak lokasi seperti membawa senjata tajam, pentungan atau balok kayu serta membawa cairan beracun. Kelompok ibu-ibu yang turun pada saat itu kericuhan di Desa Sibanggor Jae atau saat pemblokiran jalan lintas Sumatera pernah mempersenjatai diri dengan cangkul kecil atau dalam bahasa lokal disebut dengan "tajak". Menurut pengakuan tokoh perempuan sekaligus wakil Forum Srikandi, Masna Lubis, dalam setiap aksi massa menentang perusahaan ia selalu membawa pisau kecil yang ia selipkan dalam roknya. Tindakan tersebut sebagai bentuk perlindungan dirinya bagi siapun yang mencoba menghadang atau melukai dirinya pada saat aksi massa. Hal itu juga dilakukan karena ia adalah seorang perempuan yang tentunya kekuatan fisiknya tidak sama dengan lelaki jika situasi rusuh atau chaos terjadi. Pada kesempatan lain, ia sebenarnya pernah ditawari oleh anggota forum penolakan lainnya untuk membawa pistol kecil yang sempat ditunjukkan pada dirinya. Ia memang tidak dapat memastikan apakah benda yang akan diberikan tersebut adalah pistol sungguhan namun, ia menolak untuk membawa dan menggunakan senjata tersebut.

Bentuk persenjataan diri warga anti tambang yang unik adalah pembuatan cairan beracun yang dapat disiramkan pada lawan. Cairan tersebut adalah getah atau ekstrak dari biji pohon aren . Jika getah biji aren ini mengenai kulit dapat menyebabkan gatal dan pedih luar biasa. Reaksinya sangat spontan dan jika mengenai kulit pada bahagian yang luas, korban bisa saja menggaruk kulitnya sampai berdarah atau tidak bisa diam untuk selalu menggaruk bagian kulitnya yang terkena getah itu. Untuk mengelabui petugas saat aksi, mereka terlebih dahulu menumbuk halus biji pohon aren dan memasukkannya ke dalam plastik bening yang berisi air. Kantong-kantong plastik berisi cairan ekstrak biji aren tersebut ditumpukkan dalam sebuah ember besar. Sekilas, terlihat menyerupai kantong air kelapa muda yang dikira aparat atau orang lain sebagai bagian dari logistik atau air minum para demonstran. Pada kesempatan lain, Masna Lubis juga pernah membawa cairan berisi ekstrak cabe hijau dicampur dengan air mentah. Jika aksi massa berujung ricuh maka cairan ini dapat disemprotkan pada muka atau mata pihakpihak yang mencoba untuk menghalani mereka. Kedua jenis cairan ini pada faktanya tidak pernah digunakan atau disemburkan pada saat melakukan aksi massa.

Bentuk strategi selanjutnya adalah tindakan penyamaran. Pascakerusuhan Maga Lombang warga desa khususnya lelaki dewasa memilih untuk tidak berada di kampung baik siang maupun malam hari. Namun mereka menyadari bahwa roda ekonomi harus 
tetap berputar serta dapur warga tetap harus "ngepul". Tidak ada jalan lain bagi sebagaian orang untuk tetap bekerja di lahan pertaniannya. Untuk menghindari penangkapan oleh aparat kepolisian dan juga mengantisipasi hadirnya orang luar untuk mengetahui keberadaan mereka, beberapa warga melakukan penyamaran seperti dengan mengenakan pakaian perempuan saat mengerjakan lahan pertanian yang dekat dengan akses jalan menuju desa.

Afrizal Tanjung (30) menuturkan bahwa saat polisi berdatangan ke Desa Sibanggor Julu untuk mencari para tersangka, ia tetap pergi ke sawah untuk membantu orangtuanya mencari nafkah. Ia sesuai saran Ibundanya terpaksa mengenakan rok dan jilbab saat melakukan aktifitasnya di sawah yang kebetulan lokasinya dekat dengan jalan utama menuju desa. Asumsi lainnya mengenakan gaun ini bahwa perempuan saat itu tidak menjadi target kepolisian atau jarang ditanya-tanya orang luar informasi pada mereka . Untuk menghindari kecurigaan warga akan bentuk tubuhnya, ia pura-pura serius bekerja jika ada orang lain yang melintas dekat dengan sawahnya. Sedikir berbeda dengan Tafsir Lubis yang mengenakan topi perempuan atau dalam bahasa lokal disebut "songkok" saat mengerjakan lahan pertaniannya . Khawatir dengan bekas cukuran kumis dan jenggotnya diketahui petugas atau orang lain yang melintas, ia selanjutnya melumuri mukanya dengan lumpur seperti layaknya bedak muka.

"Saat itu saya harus membersihkan lahan sawah di Saba Lombang dan juga mengurusi ternak di situ, semantara polisi dari kemarin-kemarin sudah lalu-lalang di desa. Kabarnya mencari para tersangka yang melarikan diri. Ibu saya menyuruh memakai jilbab rok dan jilbab itu. Asal ada suara kenderaan atau orang yang lewat pura-pura serius aja bekerja biar nggak dicakapi (diajak bicara-pen)"

Gerilya dari polisi juga merupakan strategi bertahan hidup yang dilakukan oleh warga. Beberapa hari setelah kerusuhan di Desa Maga Lombang, forum penolakan masih menggelar zikir akbar. Kesempatan ini dimanfaatkan polisi untuk menciduk beberapa orang tersangka. Sahar, menuturkan bahwa ia adalah warga Sibanggor Julu pertama yang ditangkap polisi.Penangkapannya dilakukan polisi dengan cara menjebak ketika ada nomor baru menelponnya dan mengajaknya minum kopi pada suatu tempat, tanpa sadar ia menyampaikan tempatnya sedang minum kopi dan beberapa saat kemudia ia diciduk oleh beberapa polisi di warung kopi di Desa Pasar Maga tersebut . Sahar sore hari itu dibawa ke Mapolres Madina dan diinterogasi dalam 24 jam sekitar perannya dalam kerusuhan.

Begitu beliau keluar dari Mapolres Madina tengah malam berikutnya, warga lain secara bertubi-tubi menelponnya meminta update pemeriksaanny. Begitu sampai di desa, ia menceritakan apa yang dialaminya dan menyampaikan bahwa beberapa orang dari desa Sibanggor Julu jelas ia lihat dalam rekaman video. Penyebutan nama-nama itu ternyata berbuntut panjang dan warga desa yang merasa hadir pada saat kerusuhan sepakat bersembunyi dan melarikan diri dari kemungkinan penangkapan dari polisi. 
Persembunyian terbaik adalah ke tengah hutan antara lain di wilayah Barerang, Bargot Najaji, Laingan atau Kopi Purba. Jarak antara desa dengan wilayah-wilayah itu sekitar 1,5 sampai $2 \mathrm{~km}$. Mereka dalam beberapa hari bersembunyi di sana dan menginap pada pondok-pondok warga sebagai tempat membuat gula aren .

Tidak semua warga sanggup bersembunyi dan menginap di tengah hutan dengan berbagai alasan seperti meninggalkan isteri yang masih memiliki balita atau karena kondisi fisik yang tidak mungkin untuk berlari ke tengah hutan. Mereka memilih tetap berada di kampung halaman dengan rasa was-was yang tinggi. Pada siang hari mereka trauma melihat orang baru yang hilir mudik di desa dan dicurigai sebagai intelijen. Malam hari mencari tempat bersembunyi yang sulit diketahui orang lain dan polisi. Dalam Group Discussion diperoleh informasi seorang warga, Aswar Nasution, memilih membentangkan kain panjang yang diperlakukan layaknya ayunan bayi di atas plafon rumah dan tidur dalam buaian tersebut layaknya seorang bayi yang tidurnya harus diayun. Sedangkan warga lain, Naswan, memilih tidur di bawah kolong rumah panggung dengan menggelar tilam sebagai tempat tidur dan menaruh kayu bakar pada sisi luar kolong rumah. Afrizal juga menuturkan bahwa suatu ketika mereka sudah capek dan mengantuk sementara kalau tidur di pondok takut tertidur pulas akhirnya mereka memanjat dan berbaring di atas pakis liar yang tumbuh menyerupai payung terbalik. Namun, beberapa saat setelah ia istrirahat dan berbaring sebentar, ia dan dua orang temannya teringat bahwa tempat seperti itu rawan didatangi ular sehingga mereka langsung turun dari pohon itu dan mencari tempat lain yang dirasa lebih aman.

Para warga yang hadir saat kerusuhan dan merasa melakukan perbuatan melawan hukum seperti pencurian atau penjarahan memilih melarikan diri dari Madina. Di antara warga tersebut adalah Amri Roy Tanjung dan Landong Tanjung. Mereka melarikan diri sampai ke pulau jawa karena isunya mereka sempat mengambil uang milik korban atau mengambil hewan peliharaan (pet) milik korban seperti jenis burung, kukang dan binatang lainnya . Daerah pelarian mereka adalah kawasan Jabodetabek karena di wilayah ini banyak sanak saudara warga yang merantau dengan pekerjaan utama membuka warung sembako. Pelarian mereka sepenuhnya dibantu oleh warga yang menolak perusahaan seperti membawa menuju jalan tikus dari hutan ke jalan lintas Pantai Barat (Simpang Gambir-Ujung Gading-Padang) tidak melalui rute yang biasa dari Kotanopan-Bukittinggi-Jakarta.

Solidaritas yang tinggi dari kelompok anti tambang antara lain terlihat ketika sebagain warga membantu logistik warga yang lain yang bersembunyi di hutan. Keluarga dekat mereka secara bergeliran membawa bekal makanan ke tempat yang sudah disepakati melalui komunikasi telepon. Biasanya tempat yang dimaksud adalah wilayah persawahan atau perkebunan warga yang ada di pinggir desa. Warga pelarian yang menjemput bahan makanan tersebut dilakukan secara bergantian sehingga tidak ada gerak-gerik rombongan yang terpantau dari jauh. Bentuk perlawanan kelompok sosial 
terpinggirkan ini sejalan dengan yang disampaikan (Scott, 2008)) yang dilakukan secara sederhana seperti melangkah dan menyeret kaki.Warga lain yang bersimpati dengan warga yang melarikan diri terkadang menyelipkan beberapa bungkus rokok pada pondok-pondok yang sering dikunjungi warga pelarian dan dibiarkan diambil begitu saja oleh warga pelarian tersebut.

"Saya terpaksa membawa bekal mereka ke tengah hutan padahal saya sedang terkena malaria. Sekarung beras bulog dengan berat sekitar $40 \mathrm{~kg}$ saya pikul ke Laingan. Dengan jalan yang menanjak dan terkadang menurun saya merangkak dan hanya bisa "mosor-osor" (merangkak-pen) membawa logistik itu. Sampai akhirnya terpaksa menelepon salah satu di antara mereka untuk turun menjemput logistik yang dibawa".

Kejadian yang aneh adalah pengalaman Afrizal Tanjung ketika menjemput bekal makanan yang dikirimkan orang tuanya. Ia mengaku setelah berhari-hari di tengah hutan, bekal makanan yang ia terima suatu ketika berbeda dari sebelumnya yaitu ada kalung emas dengan berat sekitar 2 mayam emas atau sekitar 5 gram. Ia bingung memaknainya tujuan pemberian emas tersebut dan setelah pulang, orang tuanya menyampaikan bahwa ia sebaiknya melarikan diri saja dengan menjualkan kalung emas itu jika diperlukan .

Intervensi sektor hukum merupakan salah satu bentuk strategi yang dapat dimainkan kelompok tertentu dalam sebuah gerakan sosial maupun konflik (Vestana, 2017). Hal ini juga terjadi dalam konflik di area WKP Sorik Marapi. Jika dilihat dari kronologis kerusuhan massa yang memakan korban, kejadian itu diawali oleh kedatangan korban beserta rombongannya ke wilayah Maga Pasar sembari melakukan pengancaman dan pencarian terhadap pengurus forum penolakan yaitu Tan Husein dan Tan Ghozali. Atas dasar itu, anggota forum penolakan pada hampir setiap desa membuat surat pernyataan sekaligus permohonan kepada Polres Madina untuk menangkap beberapa orang yang mendampingi korban saat datang ke Pasar Maga pada malam itu. Pernyataan tersebut dibuat oleh 8 (delapan) desa dengan isi dan format yang seragam dan ditandatangani oleh para kepala desa dan tokoh lainnya. Dalam pernyataan tersebut masyarakat menyampaikan keberatannya pada teman-teman korban saat hadir pada malam kejadian dan meminta Kapolres untuk mengusut 4 (empat) orang warga Maga Lombang

"Kami mewakili masyarakat di Desa Aek Marian berkeberatan atas kejadian yang terjadi di hari Selasa tanggal 20 Januari 2015 (pagi) di Kedai Lopo Saroha, Pasar Maga. Meminta kepada Kapolres Madina untuk segera melakukan pengusutan pengancaman di kedai kopi Saroha yang berinisial sebagai berikut: 1. Uneng/Pintor Hamonangan, 2. Tuak/Martua, 3. Sutan/Ali Sutan, 4. Baringin".

Hal ini merupakan strategi warga penolak tambang untuk melakukan perlawanan sekaligus cara untuk mendesak kepolisian untuk segera menghentikan pencarian para tersangka. Menurut pengakuan mantan Camat PSM, surat pernyataan semacam ini 
adalah pola umum yang dilakukan oleh forum penolakan termasuk peraturan yang disebut mereka sebagai undang-undang atau peraturan desa yang formatnya dibuat seragam, diedarkan secara massif dan ada semacam pemaksaan kehendak kepada pemerintah desa untuk menandatanganinya .

\section{Politik Survivalitas Pejabat Pemerintahan}

Dalam terminologi yang umum, aktor politik selalu merujuk pada aktor yang memiliki jabatan-jabatan politis atau yang dipilih melalui proses politik. Pemaknaan aktor politik pada kajian ini diperluas termasuk pada mereka yang memiliki pengaruh politik sekalipun pada tataran normatifnya mereka hanyalan pejabat administratif. Hal ini juga didasari pada fakta mereka yang hanya memiliki jabatan administratif seperti Camat, Sekretaris Desa, Kaur Desa dan sebagainya juga memiliki pengaruh politik pada masyarakat yang sedang berkonflik. Politik survivalitas yang dilakukan oleh pemilik kekuasaan khususnya pejabat pemerintahan desa dan kecamatan berdasarkan kajian ini paling tidak terdiri atas tindakan non merit appointment, dirty trick, perlawanan langsung dan perlawanan diam-diam.

Kelompok yang memiliki kekuasaan resmi dalam situasi konflik kerap membuat aturan, norma dan prinsip maupun prosedur pengambilan keputusan yang menguntungkan rezim mereka sebagai bentuk dari politic of survival (Moyo, 2014). Kepentingan mendudukkan orang-orang dekat yang dinilai mampu bekerjasama di tengah konflik misalnya dilakukan oleh pejabat pemerintahan desa. Sibanggor Julu pemerintah desanya lebih banyak pada posisi netral atau mendukung kehadiran perusahan sehingga menempatkan orang-orang yang netral atau mendukung kehadiran perusahaan sebagai pejabatnya. Sedangkan Desa Hutanamale, kepala desanya lebih condong kepada pihak yang menolak aktifitas tambang sehingga menempatkan orangorang yang menolak tambang dalam struktur pemerintahannya. Penempatan seperti ini dinilai sebagai bentuk non merit appointment ketika orang-orang yang dinilai tidak layak dari segi pendidikan, kapasitas dan juga pengalaman masuk dalam jajaran pemerintahan desa (Migdal, 1988).

"Ijazah Sekdesnya tidak ada. Katanya boleh dari kantor Camat. Kepala Banjar semacam Asnawi, si Ket tamat sekolahpun tidak jelas. Bahasa melayu saja tidak bisa”

Kasus Hutanamale memang berbeda, Sekdesanya secara nyata adalah seorang PNS dan pada malam hari bekerja sebagai bagian pengamanan di PT.SMGP. Ia tidak dianggap oleh pemerintah desa sebagai bagian dari pemerintahannya. Malah, pada tahun-tahun sebelumnya, sang kepala desa adalah inisiator dibalik keluarnya putusan pemberhentiannya sebagai PNS. Sang Sekde pun, tidak diberikan tempat dalam musyawarah desa sampai tidak diberikan tempat yang layak untuk berkerja sehingga ia memilih berkantor di Kantor Camat. 
Pemilik kekuasaan dalam tujuan mempertahankan pengaruh dan eksistensinya selanjutnya melakukan tindakan licik maupun kotor (dirty trick) (Migdal, 1988). Bentuk ditry trick itu misalnya seperti apa yang dilakukan oleh kepala desa Sibanggor Julu. Pertama, ia mengarahkan pemuda dari tokoh penolakan untuk meminta bantuan dari PT.SMGP untuk kebutuhan acara peringatan Maulid Nabi Tahun 2015. Rekomendasi kepala desa ini menyebabkan dua tokoh pemuda itu diusir dari desa setelah ada yang membisikkan bahwa kedua tokoh telah menerima uang sebesar Rp. 10 juta dari perusahaan sebagaimana telah dijelaskan sebelumnya.

Kedua, kepala desa ini pernah mengalihkan barang /benda yang seharusnya menjadi aset desa dicatatkan menjadi milik pribadi. Kasus ini bermula ketika ada bantuan beberapa ekor kambing dari Dinas Pertanian, namun forum penolakan menuduh bahwa bantuan itu berasal dari perusahaan seperti halnya pemberian ternak di Sibanggor Jae beberapa waktu sebelumnya . Karena adanya tuduhan itu, kepala desa akhirnya berpurapura mengembalikan ternak itu dengan mengangkutnya kembali dengan minibus pick up miliknya. Tapi bukan untuk dikembalikan tapi dititipkan untuk diternakkan orang lain di desa Maga Lombang .

Politik mempertahankan kekuasaan yang dilakukan oleh pemilik kekuasan dalam kasus ini juga termasuk tindakan kepura-puraan dalam makna bahwa menunjukkan sikap seolah-olah mendukung kelompok minoritas tersebut atau dalam istilah (Migdal, 1988) disebut sebagai kepatuhan palsu (false compliance). Sekdes Aek Marian menuturkan bahwa pada saat mayoritas menghadiri zikir akbar di desa lain, ia sengaja berangkat dari desa untuk menghindari asumsi masyarakat sebagai pendukung perusahaan. Namun, ia sebenarnya hanya berangkat setengah perjalanan menuju lokasi pelaksanaan zikir akbar dan pulang ke desa bersamaan dengan kerumunan warga desa yang kembali pulang ke kampung halamannya.

"Saat zikir akbar di Desa Sibanggor Julu saya berangkat separuh jalan saja sampai

Teluk (Desa Hutalombang) dan pulang ke desa bersamaan dengan turunnya kembali warga desa ke kampung halaman"

Berbohong adalah tindakan lainnya yang lazim dilakukan oleh warga dalam kungkungan dominasi kelompok elit sosial, ekonomi maupun politik dalam sebuah komunitas (Migdal, 1988). Tindakan berbohong ini juga sering terjadi dalam konflik yang terjadi di area WKP Sorik Marapi. Hal ini misalnya terjadi ketika, pembongkaran tembok sebagai pintu akses menuju wellpad A yang telah dimusyawarahkan bersama oleh Muspida. Pembongkaran itu dilakukan setelah ada kesepakatan pemberian kompensasi dalam bentuk uang kepada semua pihak termasuk forum penolakan. Untuk kelompok penolakan diperkirakan pada kisaran angka Rp. 100 juta sampai Rp. 300 juta dan setiap kepala desa akan menerima sebesar Rp. 1 juta. Kepala Desa Sibanggor Julu menyatakan dengan tegas mendapatkan dana kompensasi sebesar Rp. 1 juta . Isu itu tersebar luas dan forum penolakan mencari para kepala desa untuk mencari kebenaran isu itu. Bahkan 
sampai ada kepala desa di wilayah Hutabaringin yang lari ke tengah hutan untuk menghindari massa tersebut.

Kepala Desa Sibanggor Tonga menuturkan bahwa pada malam setelah penyerahan uang itu massa penolak tambang datang berbondong-bondong menemui dirinya untuk memastikan apakah ia menerima uang itu. Menurutnya ia tidak mengambil uang "jatah" dimaksud dan meminta forum penolakan mempertanyakan hal itu secara langsung besok paginya kepada Camat PSM. Ungkapan kepala desa itu pada satu sisi ada benarnya, namun menurut mantan Camat yang sebenarnya terjadi bahwa uang "jatah" kepala desa itu sudah ia berikan pada suatu siang langsung ke tangan sang kepala desa. Namun, setelah malam ketika didatangi massa, panginya kepala desa menemui Camat dan menyampaikan kronologis kejadian pada malam harinya sembari mengembalikan uang "jatah" yang diberikan Camat pada hari sebelumnya .

Perlawanan langsung adalah bentuk stategi bertahan lainnya yang diperankan oleh kelompok elit kekuasaan di wilayah pertambangan. Mantan Sekdes Sibanggor Tonga - desa yang warganya 50\% menolak tambang dan 50\% yang lain mendukung aktifitas tambang. Pada suatu malam di tahun 2014, ia sedang melangsungkan pesta pernikahan keponakannya dan meggelar hiburan berupa keyboard yang hampir berakhir tengah malam. Ketika undangan sedang asyik menikmati hiburan, tiba-tiba ada beberapa mobil yang bannya digembosi. Selang beberapa lama, hujan batu menghantam gedung di sekitar kantor Camat tempat dilangsungkannya acara pesta. Tidak terima dengan kejadian itu, ia mengejar beberapa orang dari arah batu dilemparkan dan berhasil menangkap satu orang di antaranya yang ternyata masih remaja. Ia mencekik leher anak itu sampai kesulitan bernafas dan setelah sadar itu bisa berakibat fatal ia menghentikannya serta melepaskan si anak itu .

Begitu ia kembali ke lokasi pesta ia melihat sudah banyak pemuda yang hadir dari Sibanggor Julu untuk membantu penolak tambang di desanya. Khawatir akan terjadi perlawanan sengit dan pada fakta bahwa penduduk dari Sibanggor Julu lebih banyak ia mengambil inisiatif menelepon aparat kepolisian di kabupaten dan langsung berbicara dengan salah satu petinggi di Mabes TNI Jakarta. Selang beberapa lama akhirnya bantuan dari kepolisian datang dan massa penolakan dan massa dari Sibanggor Julu mundur dan pulang ke desa masing-masing.

Perlawanan diam-diam juga dilakukan oleh pemilik kekuasaan khususnya pejabat pemerintah desa maupun kecamatan. Bentuk perlawanan itu adalah pengembosan organisasi penolakan tambang dari dalam. Sekdes Sibanggor Jae, misalnya, menuturkan bahwa saat melakukan drafting norma atau "undang-undang desa" yang dibuat di desanya, ia merancang redaksi yang bahasanya ambigu yang dalam bahasa hukum sulit dieksekusi. Penggunaan kata "pindah" menggantikan kata "usir" dalam redaksinya ia lakukan dengan suatu maksud. Kata wajib "pindah" dari desa dalam terminologi administrasi kependudukan harus mengandung unsur pertujuan dari warga yang pindah sehingga tidak otomatis warga yang dinyatakan wajib pindah harus keluar dari desa. Pada 
kesempatan yang lain, ia secara rahasia sengaja mengumpulkan warga yang berpotensi untuk diusir untuk melakukan perlawanan. Dalam wejangannya, ia selalu menyampaikan bahwa penjualan lahan kepada perusahaan adalah hak masing-masing warga dan tidak ada unsur kepemilikan komunal dalam tanah tersebut. Oleh karenanya apapun yang menjadi alasan bagi kelompok sosial dominan untuk melakukan pengusiran tidak dapat diterima . Perlawanan diam-diam juga sempat mau dilakukan oleh Camat PSM dengan merangkul pemuda untuk membuat gerakan perlawanan atau paling tidak menetralisir situasi di tengah tingginya dominasi kelompok penolakan di area WKP Sorik Marapi. Menurut wakil ketua forum penolakan, ia sempat mendengarkan adanya rencana pertemuan yang diinisiasi oleh Camat itu di rumah pribadinya di Panyabungan. Saat mendengarkan isu itu ia langsung menebarkan ancaman kepada siapa saja yang berani untuk menghadiri pertemuan dimaksud. "Siapa yang pergi kesana, Awas!. Itu saya sampaikan kepada pemuda" .

Terakhir, bentuk survivalitas politik lain yang dilakukan oleh pejabat pemerintahan desa adalah menjadi bagian dari forum penolakan. Sekalipun hal ini dianggap aneh tetapi pada beberapa kondisi hal itu sesuatu yang logis yang dapat dilakukan mereka. Dengan bergabung menjadi bagian dari forum penolakan tersebut mereka dianggap mengikuti aspirasi warganya dan pada saat yang sama bentuk cemoohan, intimidasi maupun provokasi dari kelompok sosial dominan tidak akan mereka alami. Bagi desa yang mayoritas menolak kegiatan tambang sulit dipisahkan pada saat mana seorang pejabat pemerintahan bertindak sebagai aparat desa yang harus menganyomi semua pihak dan saat mana mereka bertindak sebagai bagian dari forum penolakan. Fakta yang jelas adalah desa Hutabaru dimana pejabat desanya sekaligus menjadi pengurus penolakan. Saifullah yang merupakan aparat pemerintah, pernah sebagai Sekdes dan kaur desa di Desa Hutabaru adalah koordinator desa untuk forum penolakan OTP. Pada kasus desa lain, Saudara Barok Nasution yang merupakan ketua BPD merupakan koordinator desa untuk forum penolakan di Desa Sibanggor Tonga. Desa Hutanamale aparatnya lebih banyak mendukung pihak penolakan . Parahnya lagi, pada desa lain Roburan Dolok di Kecamatan, Kepala Desanya atau Raja Sawer merupakan koordinator forum penolakan di desanya.

\section{Politik Survivalitas Tokoh Pegerakan}

Tokoh pergerakan pada kajian ini dimasukkan menjadi pihak yang melakukan politik survivalitas bukan strategi survivalitas sebagaimana warga lainnya karena mereka sejatinya sudah memiliki pengaruh dan kekuasaan politik pada masyarakat yang sedang berkonflik. Bedanya, mereka tidak memiliki jabatan politik formal melainkan memiliki pengaruh politik yang kuat sebagaimana (McMann, 2015) mengkategorisasinya sebagai aktor politik bukan negara (non-state actor). Bentuk politik survivalitas yang dilakukan oleh tokoh forum penolakan tambang terdiri atas pelibatan lembaga bantuan hukum 
untuk kepentingan advokasi, menyebarkan pernyataan sikap terkait isu persetujuan pimpinan forum untuk mendukung perusahaan, negosiasi dengan penyidik sampai mengerjakan proyek perusahaan untuk kepentingan mencari pendanaan dalam gerakan.

Penetapan pimpinan forum dan beberapa orang lainnya sebagai tersangka dan terdakwa karena kerusuhan di Desa Maga Lombang mengharuskan pengurus forum yang tersisa untuk meminta bantuan advokasi dan bantuan hukum. Mereka memilih menggunkan LBH lokal yang diwakili oleh Ismail yang aslinya berasal dari Desa Hutaraja yang berbatasan langsung dengan desa Purbajulu, Kecamatan PSM . Untuk menggandeng lembaga lain khususnya yang concern dengan permasalahan lingkungan hidup dan tambang seperti Walhi maupun Jatam pernah dipertimbangkan pengurus forum yang tersisa namun niat itu urung dilanjutkan. Tan Ghozali, selaku pengurus forum penolakan menilai bahwa lembaga konservasi semacam itu pada prinsipnya sepakat dengan tuntutan masyarakat namun lembaga semacam itu erat kaitannya dengan pemodal pada kasus pertambangan sehingga independensinya diragukan. Jimmy Charter, mantan presiden Amerika Serikat, yang dikenal sebagai bapak Taman Nasional saja memiliki saham pada beberapa perusahaan tambang besar di dunia. Pada faktanya juga, di mana saja ada kawasan taman nasional, di situ ada perusahaan tambang besar. Ia akhirnya berkesimpulan bahwa kehadiran lembaga-lembaga yang concern dengan konservasi tidak lebih sebagai upaya penjinakan masyarakat bersama program pemberdayaannya. Hal yang aneh lagi, Perpu No. 1/2004 memperbolehkan 13 perusahaan pertambangan di kawasan taman nasional termasuk di dalamnya pada Taman Nasional Batang Gadis di WKP Sorik Marapi. Kondisi ini tidak terlepas dari setting politik global dalam perburuan rente di sektor pertambangan.

Seiring dengan penahanan ketua forum penolakan dan para tersangka lainnya gerakan sosial penolakan tambang mulai kendur. Pengurus yang lain mulai takut akan diperlakukan sama sebagai tersangka dan sebagainya. Seiring dengan dimulainya kembali kegiatan ekspolorasi pasca mendapatkan izin baru dari kementerian ESDM April 2015 gerakan penolakan mulai melakukan berbagai bentuk konsolidasi untuk melakukan gerakan sosial lanjutan menentang aktifitas tambang. Isu-isu tidak sedap juga mulai bertebaran di masyarakat seperti adanya ketidaksamaan visi antara Herman Nasution dan Tan Ghozali serta beberapa warga yang menjenguk Herman Nasution yang menyampaikan pesan kepada mereka kalau mau bekerja dengan perusahaan sudah di perbolehkan. Mendengar isu liar tersebut, Muhlis Nasution sebagai Plt Ketua umum menggantikan Herman Nasution mengeluarkan selebaran pernyataan pada tanggal 17 Oktober 2015 yang dikutip berikut ini:

"Menyatakan bahwa isu-isu yang berkembang di masyarakat yang dilontarkan oleh pihak ketiga atau orang yang tidak bertanggungjawab "provokator" tentang pernyataaan Bapak Herman Nasution alias Ayah Mandailing alias Ompung Herman yang menyuruh masyarakat untuk masuk kerja ke PT. SMGP/OTP tidak benar (fitnah). Beliau mengatakan bahwa tetap konsisten, komitmen bersama masyarakat memperjuangkan penolakan PT. SMGP/OTP”. 
Bentuk politik survavilitas lainya adalah melakukan negosiasi sekaligus pengancaman terhadap aparat penegak hukum. Menurut Mukhlis Nasution, salah satu warga yang akan ditetapkan sebagai tersangka di luar nama 11 orang yang sudah diberitakan adalah Ketua Forum Srikandi, Siti Rohani alias Kak Lom. Namun, lobi-lobi terus dilakukan oleh Tan Ghozali dengan kepolisian untuk tidak meningkatkan status warga yang 20 orang lagi sebagai tersangka. Lobi yang dilakukan adalah lobi tingkat tinggi yang disertai dengan ancaman. Jika kepolisian menangkap Kak Lom maka massa akan membakar Stasiun Pompa Bakar Umum (SPBU) Kotanopan.

Penetapan beberapa warga anti tambang sebagai tersangka menjadikan pengurus foum yang tersisa merasa punya beban moral untuk memperhatikan nasib anggota keluarga mereka karena mayoritasnya adalah orang tua yang memiliki tanggung jawab untuk memberikan nafkah buat anak dan istrinya. Forum penolakan melakukan berbagai cara untuk mendapatkan dana untuk meringankan beban keluarga para tersangka. Selain melakukan pengutipan uang dan beras door to door, forum penolakan melalui Tan Ghozalli, mengambil keputusan untuk melaksanakan proyek yang sedang dikerjakan oleh PT. SMGP pasca take over dari pemilik saham lama Origin, Tata Power dan Supraco kepada pemilik saham baru ORKA . Namun dalam pengakuannya, bukan berarti forum telah melunak atau mau bekerja dengan perusahaan melainkan proyek yang dikerjakan diambil dari skema pendanaan CSR PT. SMGP yang pada hahikatnya adalah milik masyarakat, uang masyarakat. Dana yang diperoleh dari kegiatan itu tidak besar dan mereka peruntukkan membantu para tersangka termasuk membiayai profesional hukum dalam kasus itu.

"Waktu take over. Saya memanfaatkan dana-dana dari CSR untuk membantu masyarakat yang tersandung hukum. Persoalan CSR itu hak bersama masyarakat. Apa salahnya kita ambil itu. Kita minta CSR nya untuk menutupi masalah hukum. Di kasih melalui pengelola di sini. Kita bukan sebagai kontraktor di situ"

\section{Politik Survivalitas Aktor Politik Lokal}

Terminologi aktor politik lokal yang disampaikan pada bahagian ini adalah mereka yang sedang menduduki jabatan politik formal atau mereka yang sedang berjuang untuk menduduki jabatan politik formal itu seperti anggota DPRD maupun kontestan Pemilu dan Pemilukada. Bentuk politik survivalitas yang mereka lakukan antara lain menjadikan pemuda sebagai entry point dalam kampanye, aksi kepedulian, dukungan diam-diam untuk kelompok anti tambang, mengangkat isu kampanye sesuai kehendak mayoritas, memanfaatkan jaringan nepotisme sampai memanfaatkan birokrasi.

Pemilu pada masa orde lama dan orde baru, peran kampanye tidak terlalu signifikan dalam meningkatkan popularitas dan elektabilitas partai politik di wilayah ini. Afiliasi partai politik dengan mengaitkannya dengan latar belakang keagamaan (NU) 
menjadi pendekatan pokok dalam perilaku memilih sehingga profil para calon kontestan tidak menjadi faktor penting. Hal ini sejalan dengan pendapat Dalton dalam fenomena yang sama dalam pemilu di wilayah Selatan Amerika Serikat dengan adagiumnya bahwa "they would vote for anyone, even a yellow dog, if they were a Democrat" (Dalton, 2016). Pada pemilu legislatif tahun 2014, kontestan pemilu melakukan berbagai strategi untuk memenangkan kontestasi di daerah konflik. Jika ditilik dari pola perilaku pada beberapa pemilu legislatifnya sebelumnya, basis identitas (sosiologis), afiliasi partai (psikologis) dan rekam jejak dan visi misi kandidat (pilihan rasional) belum mendapatkan tempat menjadi sebuah pola mayoritas di wilayah ini (Haryanto, 2014), menurut Holmes (2008) melainkan dominasi politik uang yang digunakan oleh para kontestan.

Jika pada pemilu-pemilu sebelumnya bentuk politik uang dilakukan dengan memberikan uang tunai secara langsung, maka PDI Perjuangan atas nama Abdul Rahim datang dengan metode yang berbeda: memanfaatkan pemuda Sibanggor Julu sebagai titik masuk dengan janji meratakan (levelling) lapangan sepakbola yang puluhan tahun tidak pernah terealisasi. Entry point ini bagaimanapun sangat strategis karena pada saat konflik memuncak, pemuda termasuk di dalamnya remaja perempuan adalah unsur paling depan dalam pergerakan menolak tambang:

"Si Rahim datang bukan dengan uang, tetapi masuk pada pemuda desa dengan janji akan merealisasikan perataan lapangan sepakbola milik desa sesuai permintaan pemuda-pemuda desa. Ia tidak melakukan pemberian uang seperti caleg-caleg lainnya. Janji itu ia realisasikan beberapa hari sebelum pemungutan suara. Alhasil, pemuda merasa bertanggungjawab untuk memenangkannya dengan menggandeng nauli bulung (organisasi remaja perempuan desa) merealisasikannya. Ia menjadi pemenang di Sibanggor Julu dan berhasil duduk sebagai DPRD"

Dalam situasi konflik di WKP beberapa anggota DPRD Kabupatem maupun Provinsi menunjukkan kepeduliannya dengan memberikan simpati pada demonstran yang melakukan aksi massa pada beberapa lokasi di Kabupaten. Aksi simpati ini misalnya dilakukan oleh Abdur Rahim sebagai pemenang kontestasi Pileg 2014 pada desa terbesar kedua di Kecamatan PSM atau Desa Sibanggor Julu. Ia misalnya secara langsung hadir dalam demostrasi massa pada saat pemblokiran jalan di desa Purbalamo tanggal 11 November 2014 sebagaimana direkam oleh media lokal Metro Tabagsel . Komitmennya juga disampaikan di tengah polemik antara memberikan dukungan atau penolakan atas kehadiran perusahaan yang ditunjukkan oleh sesama anggota DPRD dari fraksi yang sama, Hasahatan Nasution, yang dalam rekaman media menunjukkan sikap yang berbeda yaitu memberikan dukungan terkait dengan kehadiran PT. SMGP. Aksi simpatik lain ditunjukkan oleh Sutrsno Pangaribuan, anggota DPRD Sumut periode 2014-2019 dari Dapil Sumut 7 yang antara lain meliputi wilayah Kabupaten Madina. Dalam sebuah pertemuan resmi yang digelar antara pemerintah provinsi, kabupaten dan pihak PT. SMGP pada tanggal 18 Februari 2015 ia menyampaikan pentingnya 
memperhatikan keselamatan masyarakat dari pada memperjuangkan sebuah proyek raksasa yang telah menimbulkan konflik di tengah masyarakat.

Pada saat gerakan sosial sedang memuncak yang disertai dengan intensitas pelaksanaan demonstrasi massa di berbagai tempat, ada beberapa tokoh politik seperti anggota DPRD yang secara sembunyi-sembunyi memberikan simpati bagi kelompok penolakan. Bentuk simpati itu adalah memberikan sekedar "uang minum" atau "uang rokok" bagi para pengurus penolakan. Bupati pun sendiri pun selalu memberikan uang rokok setiap selesai melakukan demosntrasi . Salah satu pengurus penolakan yang sering mendapatkan bentuk simpati tersebut adalah Syarifuddin Lubis yang pada saat itu bertindak sebagai ketua Forum Muda Mudi Sibanggor Julu, organisasi sayap bentukan forum penolakan. Dalam wawancara ia menyampaikan bahwa kalau saat melakukan aksi, bupati melalui anggota DPRD dari Fraksi PKB sering memberikan uang rokok dam selalu memberikan nasehat untuk jangan menjadi "penonton" saja dalam proyek pertambangan panas bumi.

Tindakan kolaboratif dan aliansi dalam situasi konflik merupakan modus umum yang dilakukan oleh aktor politik. Kolaborasi itu termasuk dilakukan dengan tokoh adat (clan leaders), tokoh pergerakan maupun local strongman (Simmons, 2014). Apa yang dilakukan oleh anggota DPRD pada kasus di atas merupakan bentuk politic of strategies dengan harapan tetap terjadi komunikasi yang berkelanjutan antara aktor politik itu dengan tokoh-tokoh pergerakan.

Dalam kepentingan meraup suara di area WKP Sorik Marapi, mengangkat kehendak mayoritas terkait penghentian aktifitas tambang merupakan strategi paling tepat karena secara psikologis masyarakat ingin memilih kontestan yang satu visi dan komitmen yang sama dengan mereka yaitu menolak aktifitas tambang. Pemanfaatan isu kontemporer seperti ini lazim juga digunakan sebagai basis dalam perilaku memilih seperti isu pengangguran, inflasi, asuransi kesehatan maupun jaminan pekerjaan pada pemilu Amerika tahun 1776 (Dalton, Farrell, \& McAllister, 2011).

Situasi konflik dan isu yang berkembang di WKP Sorik Marapi dimanfaatkan oleh salah satu kontestan, Safaruddin Haji. Dalam kiprahnya sebagai Ketua Kadin Madina, jauh-jauh hari sebelum tahapan kontestasi di awal tahun 2015, ia sudah menghembuskan aksi penolakan terhadap kegiatan eksplorasi tambang sebagaimana dikutip dalam rekaman media lokal, Analisa tanggal 9 Desember 2014. Syafaruddin Haji mengakui dekat dengan pengurus forum penolakan karena komitmennya menolak segala aktifitas yang merusak alam dan komitmen tersebut akan ia jalankan mana kala ia terpilih menjadi bupati. Dengan tegas ia menyatakan bahwa "jika terpilih tidak akan pernah izin diberikan kepada perusahaan panas bumi". Sebagai upaya memperjuangkan visinya tersebut, ia melakukan "pencerahan" kepada forum penolakan termasuk kepada salah satu pengurusnya, Mukhlis Nasution, dalam beberapa kali pertemuan. Pencerahan itu adalah potensi kerusakan alam karena aktifitas pertambangan dan bahaya investasi China melalui proyek OBOR China yang mulai marak di Madina . Posisinya secara nyata ia 
sampaikan bahwa jika ia kelak terpilih sebagai Bupati Madina periode 2015-2020 tidak akan pernah memberikan izin operasi kepada perusahaan ".

Tabel 1. Posisi Pasangan Calon Terkait Isu Eksplorasi Panas Bumi

\begin{tabular}{c|llll}
$\begin{array}{c}\text { No } \\
\text { Urut } \\
\text { Paslon }\end{array}$ & \multicolumn{1}{c}{$\begin{array}{c}\text { Nama Paslon } \\
\text { (Disingkat) }\end{array}$} & \multicolumn{1}{c}{ Sikap } & Aksi Real & \multicolumn{1}{c}{ Komitmen } \\
\hline 1 & Yusuf/ Imron & $\begin{array}{l}\text { Berada pada posisi } \\
\text { pemerintah }\end{array}$ & Normatif & $\begin{array}{l}\text { Mencari solusi } \\
\text { terbaik }\end{array}$ \\
2 & Dahlan/Suheri & $\begin{array}{l}\text { Berada pada posisi } \\
\text { pemerintah }\end{array}$ & Normatif & $\begin{array}{l}\text { Mencari solusi } \\
\text { terbaik }\end{array}$ \\
3 & Syafaruddin/Miswar & $\begin{array}{l}\text { Berada pada sisi } \\
\text { masyarakat }\end{array}$ & $\begin{array}{l}\text { Menolak } \\
\text { kehadiran } \\
\text { perusahaan }\end{array}$ & $\begin{array}{l}\text { Konsisten } \\
\text { memperjuangkan } \\
\text { penolakan } \\
\text { perusahaan }\end{array}$ \\
& & & & \\
& & &
\end{tabular}

Sumber: Hasil Penelitian, 2019

Jejaring nepotisme dengan memanfaatkan hubungan kekerabatan, keturunan dan perkawinan adalah salah satu modus yang umum yang digunakan dalam kontestasi pemilu (Arisandi, 2016; Sinaga, 2019). Yusuf Nasution adalah satu-satunya kontestan yang dianggap sebagai putra daerah dari WKP Sorik Marapi. Leluhurnya berasal dari Desa Hutabaringin Maga di Kecamatan PSM dan keluarga serta kerabat dekatnya banyak yang tinggal di area WKP. Jaringan kekerabatan (nepotism) ia lakukan dalam kontestasi Pilkada 2015 dan terbukti efektif dalam mendulang suara di desa Hutabaringin, Hutabaringin Julu dan Hutanamale dengan catatan perolehan suara sebanyak 61,87 \% dari 1.078 suara sah pada 3 ketiga desa. Calon ini juga dikenal memiliki track record yang bagus dalam membantu masyarakat di kawasan 3 desa tersebut seperti menyalurkan bantuan uang tunai pada anak yatim, fakir dan miskin, mengangkat beberapa warga sebagai PNS atau tenaga pada kantor pemerintah kabupaten . Beliau juga dikenal sebagai pengurus lembaga wakaf dan pendidikan agama $\mathrm{Al}$ Junaidiyah di wilayah tersebut. Jika dikaitkan dengan afiliasi calon dengan organisasi keagamaan yang ada serta fakta bahwa perwakafan mengusung paham-paham keagamaan NU dalam manajemen dan pendidikannya, hal itu tidak menarik untuk dibicarakan bagi warga setempat sekalipun Yusuf adalah pengurus Muhammadiyah karena manfaat kehadiran beliau dalam perwakafan telah dirasakan oleh masyarakat. Basis perilaku memilih dengan memanfaatkan jaringan nepotisme ini merupakan bentuk pendekatan sosiologis menurut George Simmel (Roth, 2008; Sulardi, 2012).

Pemanfaatan birokrasi dalam kontestasi pemilu adalah modus yang jamak dilakukan di Indonesia sejak orde baru sampai pasca reformasi (Alamsyah, 2003; Firnas, 2016). Fenomena yang sama terjadi juga dalam kontestasi Pilkada Madina tahun 2015. Salah satu calon dalam kontestasi itu Yusuf Nasution menyatakan semua kontestan menggunakan birokrasi, namun pada faktanya petahana lebih intens dan lebih massif dalam penggunaan jalur ini . Jika pasangan non petahana bergerak pada level birokrasi yang lebih tinggi, petahana menggunakan jalur ini sampai pada tingkat bawah malah 
bukan hanya melibatkan PNS tetapi juga tenaga honorer pada pemerintah daerah. Untuk wilayah utama WKP Sorik Marapi, petahana menggunakan pegawai Eselon III yang berasal dari kecamatan ini sebagai tim kampanye tidak resmi dibantu seorang pegawai honorer pada salah satu SD Negeri di Kecamatan Tambangan. Taktik mereka begitu matang dan terkenal agak kasar seperti mendatangi rumah PNS yang dinilai "keluar dari barisan". Amir Nasution yang isterinya bekerja sebagai PNS, suatu malam didatangi oleh tim sukses petahana ini dan disampaikan bahwa isunya ia mendukung pasangan non petahana serta nama istrinya akan dilaporkan kepada Bupati. Sempat syok dengan kejadian itu karena khawatir isterinya akan dipindahkan ke tempat yang jauh seperti ke wilayah Pantai Barat, ia sampai menghubungi kerabatnya yang juga anggota DPRD Madina.

\section{Penutup}

Gerakan sosial dalam kajian ini terjadi karena gagalnya institusi negara untuk melakukan kewenangan yang diperlukan untuk menjawab kepentingan dan tuntutan warganya dalam kasus pertambangan. Munculnya strategi dan politik survivalitas yang sifatnya konvensional dan inkonvensional muncul sebagai jawaban warga untuk mempertahankan kebutuhan psikologisnya dan kepentingan aktor politik untuk merawat dan mempertahankan kekuasaan dan pengaruhnya di tengah konflik. Menempatkan kembali relasi negara-masyarakat pada posisi ideal dimana negara menjadi otoritas utama dalam melakukan kontrol sosial adalah satu jawaban yang dapat menghentikan gerakan sosial dan meminimalisir konflik yang terjadi.

\section{Ucapan Terima Kasih}

Terima kasih kepada semua pihak yang turut berkontribusi pada pendalaman diskusi selama proses penyusunan artikel.

\section{Pendanaan}

Penulis tidak menerima bantuan pembiayaan untuk penelitian, kepenulisan (authorship), dan publikasi dari pihak manapun

\section{Daftar Pustaka}

Abbass, I. M. (2012). No Retreat No Surrender: Conflict For Survival Between Fulani Pastoralists and Farmers in Northern Nigeria. European Scientific Fournal, $8(1), 331-346$.

Alamsyah, A. (2003). Politik dan Birokrasi: Reposisi Peran Birokrasi Publik dalam Proses Politik Lokal. Jurnal Administrasi Publik, 2(1).

Arisandi, R. S. (2016). Praktik Politik Nepotisme dalam Pemilihan Walikota. Politik, 12(2), 1867-1878. 
Creswell, J. W. (2015). Penelitian Kualitatif \& Desain Riset: Memilih Diantara Lima Pendekatan. Yogyakarta: Pustaka Pelajar.

Dalton, R. J., Farrell, D. M., \& McAlliste, I. (2011). Political Parties and Democratic Linkage: How Parties Organize Democracy. Oxford: Oxford Scholarship.

Evans, J. A. J. (2004). Voters and Voting: An Introduction. Sage.

Firnas, M. A. (2016). Politik Dan Birokrasi: Masalah Netralitas Birokrasi di Indonesia Era Reformasi. Jurnal Review Politik, 6(01), 160-194.

Fjelde, H., \& Höglund, K. (2016). Electoral Institutions and Electoral Violence In Sub-Saharan Africa. British Fournal of Political Science, 46(2), 297-320.

Haris, S., Surbakti, R., Bhakti, I. N., Isra, S., Ambardi, K., Harjanto, N., ... Nurhasim, M. (2014). Pemilu Nasional Serentak 2019. Retrieved from http://www.rumahpemilu.com/public/doc/2015_02_06_01_35_09_Execu tive Summary Pemilu Serentak 2019.pdf

Haryanto, H. (2014). Kebangkitan Party ID: Analisis Perilaku Memilih dalam Politik Lokal di Indonesia. Furnal Ilmu Sosial Dan Ilmu Politik, 17(3), 291-308.

Hasan, N. (2006). Laskar Fihad: Islam, Militancy, and the Quest for Identity in Post-New Order Indonesia. New York: Cornell Southeast Asia Program Publications.

Holmes, P. (2008). Introducing Politics for AS level. Polity.

Kilgore, D. W. (1999). Understanding Learning in Social Movements: A Theory of Collective Learning. International Journal of Lifelong Education, 18(3), 191-202.

Lambach, D. (2004). State in Society: Joel Migdal and The Limits of State Authority. In Conference "Political Concepts Beyond the Nation State: Cosmopolitanism, territoriality, democracy", Danish Political Theory Network Conference, Uniwersity of Copenhagen, Department of Political Science Copenhagen (pp. 27-30).

McMann, K. M. (2015). Corruption As a Last Resort: Adapting to the market in Central Asia. Cornell University Press.

Migdal, J. S. (1988). Strong Societies and Weak States: State-Society Relations and State Capabilities in The Third World. Princeton University Press.

Moyo, S. (2014). Regime Survival Strategies in Zimbabwe After Independence. Fournal of International Relations and Foreign Policy, 2, 103-114.

Oliver, P. E., Cadena-Roa, J., \& Strawn, K. D. (2003). Emerging Trends in The Study of Protest and Social Movements. Research in Political Sociology, 12(1), 213-244.

Roth, D. (2008). Studi Pemilu Empiris: Sumber, Teori-teori, Instrumen dan Metode. Fakarta: Fùr Die Freiheit.

Sagala, B. D., Chandra, V. R., \& Purba, D. P. (2016). Conceptual Model of Sorik Marapi Geothermal System Based on 3-G Data Interpretation. Proceedings of IIGCE 2016.

Scott, J. C. (2008). Weapons of The Weak: Everyday Forms of Peasant Resistance. Yale University Press.

Simmons, J. T. (2014). Inheriting Failure: An Exploratory Study of Post-Colonial Somalia. Naval Postgraduate School Monterey Ca Defense Analysis Dept.

Sinaga, F. A. (2019). Bentuk-Bentuk Korupsi Politik. Furnal Legislasi Indonesia, 16(1), 59-75.

Sjaf, S. (2014). Politik Etnik: Dinamika Lokal di Kendari. Yayasan Pustaka Obor 
Indonesia.

Sulardi. (2012). Menuju Sistem Pemerintahan Presidensïl Murni. Malang: Setara Press.

Tentang Penulis

Abdul Rozak adalah dosen Pasca Sarjana Ilmu Politik, Universitas Padjadajaran, tertarik pada kajian konflik dan politik elit.

Dede Sri Kartini adalah dosen Fakultas Ilmu Sosial dan Ilmu Politik, Universitas Padjajaran, memiliki area riset seputar partai dan pemilu.

Yusa Djuyandi adalah dosen Fakultas Ilmu Sosial dan Ilmu Politik, Universitas Padjajaran, memiliki area riset seputar studi keamanan dan komunikasi politik. 